\title{
Factors affecting the profitability of Nepalese insurance companies
}

\author{
Laxmi Kumar Sah ${ }^{1 *}$, Manisha Rana Magar ${ }^{2}$
}

*Corresponding author, e-mail: sahlaxmi646@gmail.com

\begin{abstract}
This study examines the factors affecting profitability in the context of Nepalese insurance companies. Return on assets and return on equity are selected as the dependent variables. The selected independent variables are liquidity, tangibility, premium growth, firm age and firm size. The study is based on secondary data of 21 insurance companies with 168 observations for the period from 2011/12 to 2018/19. The data is collected from the reports published by Beema Samiti and Annual Reports of selected insurance companies. The regression models are estimated to test the factor affecting the profitability of Nepalese insurance companies.

The study showed that firm size has a positive impact on return on assets and return on equity. It indicates that larger firm size leads to increase in return on assets and return on equity. Likewise, premium growth has a positive impact on return on assets and return on equity. It indicates that higher the premium growth, higher would be the return on assets and return on equity. Moreover, firm age has a positive impact on return on assets. It indicates that an increase in firm age leads to increase in return on assets and return on equity. Moreover, assets tangibility has a positive impact on return of assets and return on equity. It means that higher the assets tangibility, the higher would be the return of assets and return on equity. Likewise, there is a negative impact of liquidity ratio on return on assets and return on equity. It means that an increase in liquidity ratio leads to decrease in return on assets and return on equity.
\end{abstract}

Keywords: Return on assets, return on equity, liquidity, tangibility, premium growth, firm age and size.

\section{Introduction}

Profitability is fundamental for any firm to retain a competitive advantage and facilitate long-term prosperity. It is widely used to measure the performance of financial institutions all over the world. It is one of the most important objectives of financial management since one of the main tasks and goals of financial management is to increase shareholders' wealth. A well-developed insurance sector is a boon for economic development as it provides long-term funds for infrastructure development at the same time strengthening the risk-taking ability of the country. Financial institutions encompass a broad range of business operations within the financial services sector including banks, trust companies, insurance companies, brokerage firms, and investment dealers. It plays a significant role in the socio-economic growth and development of a nation. The insurance sector plays important role in the financial services industry in almost all developed and developing countries, contributing to economic growth, efficient resource allocation, reduction of transaction costs, creation of liquidity, facilitation of economics of scale in investment, and spread of financial losses. It plays a significant role in a country's economic growth and offers financial protection to individuals or firms against monetary losses suffered from unforeseen circumstances (Ismail, 2016). The insurance sector plays a vital role in the service-based economy and its services are now being integrated into the wider financial industry.

\footnotetext{
${ }^{1}$ Uniglobe College, Pokhara University, Kathmandu

${ }^{2}$ Uniglobe College, Pokhara University, Kathmandu
} 
Greene and Segal (2004) argued that the performance of insurance companies in financial terms is normally expressed in net premium earned, profitability from underwriting activities, annual turnover, return on investment and return on equity. Chen et al. (2009) showed that profitability of insurance companies' decrease with the increase in equity ratio. The functional status of insurers does not affect the profitability of being insured but public coverage has significant impact on profitability of insurance companies. Malik (2011) investigated the determinants of profitability in insurance companies of Pakistan. The study showed that there is a significant positive association between size of the company and profitability. The result also showed that the volume of capital is significantly and positively related to profitability. Loss ratio and leverage ratio have negative but significant relationship with profitability. Ahmed et al. (2011) found that performance of Pakistan life insurance companies is determined by size, risk and leverage.

Shiu (2004) assessed the determinants of the performance of the UK general insurance companies, over the period 1986-1999 using three key indicators: investment yield, percentage change in shareholders' funds and return on shareholders' funds. The study showed that the performance of insurers have a positive correlation with the interest rate, return on equity, solvency margin and liquidity. However, there is a negative correlation of firm performance with inflation and reinsurance dependence. Similarly, Ikonic et al. (2011) analyzed the profitability of the Serbian insurance companies by applying IMF CARMEL methodology. The study revealed that capital adequacy is vital for a company as it generate a good level of profitability. In addition, Kozak (2011) examined the determinants of the profitability of 25 general insurance companies from Poland during 2002-2009. By applying a regression model, the study found that growth of gross written premiums, operating costs reduction, GDP growth and growth of the market share of the companies with foreign ownership have a positive impact on the performance of insurance companies. Moreover, Mwangi and Murigu (2015) argued that firm size has a negative relationship with the profitability of insurance companies. However, leverage has a positive relationship with profitability.

Burca and Batrinca (2014) analyzed the determinants of the financial performance in the Romanian insurance market during the period 2008-2012. The study concluded that the underwriting risk has a negative effect on financial performance. It implies that taking an excessive underwriting risk can affect the company's stability through higher expenses. The study also showed that there is a positive linkage between firm size and the insurers' financial performance. It indicates that larger firms have more resources, better risk diversification, complex information systems and better expenses management. Moreover, the insurance financial leverage reflects the potential impact of technical reserves' deficit on equity in the event of unexpected losses and has a negative influence on the financial performance. Moreover, Curak et al. (2011) assessed the determinants of the financial performance of the Croatian composite insurers between 2004 and 2009. By applying panel data technique, the study showed that company size, underwriting risk, inflation and return on equity have a significant influence on insurers' profitability.

Almajali et al. (2012) analyzed the insurance companies listed on the Amman Stock Exchange during 2002-2007. The study showed that liquidity, leverage, company size and management competence index have a significant positive effect on financial performance of the insurers. Similarly, Pervan et al. (2012) assessed the factors affecting the profitability of the insurance companies between 2005 and 2010. By using a dynamic panel 
model with GMM estimator, the study showed a significant negative influence of the loss ratio on profitability. Similarly, the study also showed a significant positive influence of age, market share and past performance on current performance. Furthermore, Mehari and Aemiro (2013) examined the impact of the Ethiopian insurance companies' characteristics on their performance. The study included 9 insurance companies which are analyzed through panel data technique during 2005-2010. The results showed that company size, loss ratio, tangibility and leverage have significant impact on the insurance companies' profitability. However, growth of gross written premiums, age and liquidity have an insignificant impact on the insurance companies' profitability.

In the context of Nepal, Upadhyaya (2020) found that firm size have positive impact on return on assets. However, leverage ratio and liquidity ratio have negative impact on return on assets. On contrary, leverage ratio has a positive impact on return on equity. Jaishi and Poudel (2021) found that leverage, firm size, liquidity and tangibility have positive and significant impact on the financial performance of Nepalese insurance companies. Pradhan and Shrestha (2015) found that liquidity is negatively and insignificantly related to return on equity. Ojha (2018) revealed that leverage has a positive and significant correlation with return on assets but negative and significant correlation with return on equity. Likewise, Pradhan (2014) found that liquidity is negatively related to firm profitability. Poudel (2019) found that there is a positive relationship of size with efficiency of bank in Nepal. In addition, Budhathoki et al. (2020) showed that bank size has a positive impact on return on assets. It indicates that larger the bank size, higher would be the return on assets. Moreover, Dahal et al. (2020) examined the liquidity management and financial performance of Nepalese insurance companies. The results showed that insurance premium has positive impact on return on assets and earnings per share. It means that increase in insurance premium leads to increase in return on assets and earnings per share. Likewise, firm size has positive impact on return on assets and earnings per share. It indicates that increase in firm size leads to increase return on assets and earnings per share. The study also concludes that insurance premium followed by current ratio and firm size is the most influencing factor that explains liquidity management and financial performance of Nepalese insurance companies.

The above discussion shows that empirical evidences vary greatly across the studies on the determinants of firm profitability. Though there are above mentioned empirical evidences in the context of other countries and in Nepal, no such evidence using more recent data exists in the context of Nepal. Therefore, in order to support one view or the other, this study has been conducted.

The main purpose of the study is to analyze the determinants of profitability of Nepalese insurance companies. Specifically, it examines the impact of firm size, liquidity, age of firm, premium growth and tangibility on return on assets and return on equity of Nepalese insurance companies. The remainder of this study is organized as follows. Section two describes the sample, data and methodology. Section three presents the empirical results and the final section draws the conclusion.

\section{Methodology}

The study is based on the secondary data which were gathered from 21insurance companies with 168 observations for the period from 2011/12 to 2018/19. The main sources of data include reports published by Beema Samiti and Annual Reports of selected insurance companies. Table 1 shows the list of insurance companies selected for the study along with the study period and number of observations. 
Table 1: List of insurance companies selected for the study along with study period and number of observations

\begin{tabular}{llc}
\hline Name of the insurance companies & Study period & Observations \\
\hline Premier Insurance Company (Nepal) Limited & $2011 / 12-2018 / 19$ & 8 \\
Siddhartha General Insurance Limited & $2011 / 12-2018 / 19$ & 8 \\
Shikhar Insurance Company Limited & $2011 / 12-2018 / 19$ & 8 \\
Neco Insurance Limited & $2011 / 12-2018 / 19$ & 8 \\
Lumbini General Insurance Limited & $2011 / 19-2018 / 19$ & 8 \\
NLG Insurance Company Limited & $2011 / 19-2018 / 19$ & 8 \\
Nepal Insurance Company Limited & $2011 / 12-2018 / 19$ & 8 \\
United Insurance Limited & $2011 / 12-2018 / 19$ & 8 \\
Prudential Insurance Company Limited & $2011 / 12-2018 / 19$ & 8 \\
Prabhu Insurance Company Limited & $2011 / 12-2018 / 19$ & 8 \\
Everest General Insurance Limited & $2011 / 12-2018 / 19$ & 8 \\
Sagarmatha General Insurance Limited & $2011 / 12-2018 / 19$ & 8 \\
IME General Insurance Limited & $2011 / 12-2018 / 19$ & 8 \\
Himalayan General Insurance Limited & $2011 / 12-2018 / 19$ & 8 \\
Gurans Life Insurance Limited & $2011 / 12-2018 / 19$ & 8 \\
Asian Life Insurance Limited & $2011 / 12-2018 / 19$ & 8 \\
Prime Life Insurance Limited & $2011 / 12-2018 / 19$ & 8 \\
Nepal Life Insurance Company Limited & $2011 / 12-2018 / 19$ & 8 \\
Life Insurance Cooperation (Nepal) limited & $2011 / 12-2018 / 19$ & 8 \\
Surya Life Insurance Limited & $2011 / 12-2018 / 19$ & 8 \\
\hline National Life insurance Company Limited & $2011 / 12-2018 / 19$ & 8 \\
\hline
\end{tabular}

Thus, the study is based on the 168 observations.

The model

The model used in this study assumes that firm profitability depends on different firm specific variables. The selected independent variables are firm size, liquidity, age of firm, premium growth and tangibility. The dependent variables are return on assets and return on equity. Therefore, the following model equations are designed to test the hypothesis.

ROAit $=\beta 0+\beta 1$ LIQit $+\beta 2$ TAit $+\beta 3$ FSit $+\beta 4$ AFit $+\beta 5$ PGit + eit

ROEit $=\beta 0+\beta 1$ LIQit $+\beta 2$ TAit $+\beta 3$ FSit $+\beta 4$ AFit $+\beta 5$ PGit + eit

Where,

ROA = Return on assets is measured as the ratio of net income to total assets, in percentage.

$\mathrm{ROE}=$ Return on equity is measured as the ratio of net income to shareholder equity, in percentage.

$L I Q=$ Liquidity is measured as the ratio of current assets to current liabilities.

$T A=$ Tangibility assets is measured as the total fixed assets to total assets, in percentage.

$P G=$ Premium growth is measured by the percentage growth of gross written premiums, in percentage.

$\mathrm{FS}=$ Firm size is measured as natural logarithm of total assets of insurance companies.

$\mathrm{AF}=\mathrm{Age}$ of the company is measured as natural logarithm of the number of years from the date of establishment.

The following section describes the variables used in this study along with hypothesis formulation. 
Return on assets

ROA provides good information about a firm's financial performance in the terms of using assets to create income. Xuezhui and Dickson (2012) found that bank's profitability has negative relationship with the core capital ratio. However, Kleff and Weber (2008) revealed that the capital level is positively correlated to the return on assets. Likewise, Bektas (2014) found a positive relationship between bank risk and capitalization. Lamberg and Valming (2009) suggested that the adaptation of liquidity strategies have an insignificant impact on ROA. Only increased use of liquidity forecasting and short-term financing during financial crisis had a positive impact on ROA. Ismail (2016) found that liquidity variables such as current ratio and cash conversion cycle have significant positive impact on profitability (ROA).

Return on equity

ROE measures a company's profitability which reveals how much profit a company generates with the money shareholders have invested. Arbiyan and Safari (2009) found a positive relationship between short-term debts and profitability (ROE) but a negative relationship between long-term debts and ROE. Mohd-Zaid et al. (2014) found that liquidity and size have significant relationships with ROE. Shil et al. (2015) revealed that there is negative significant relationship between volume of capital and leverage with financial performance (ROE) and there is insignificant positive relationship of tangibility and liquidity with financial performance (ROE).

Firm size

Upadhyaya (2020) found that firm size have positive impact on return on assets. Poudel (2019) found that there is a positive relationship of size with efficiency of bank in Nepal. In addition, Budhathoki et al. (2020) showed that bank size has a positive impact on return on assets. However, Browne et al. (2001) found that the company size has a positive relationship with the financial performance of life insurance companies. Similarly, Dey et al. (2015) assessed the factors determining financial performance of life insurance companies of India. The study revealed that there is a positive relationship between financial performance and size of insurance companies. Cooke (1992) examined the impact of size, stock market listing and industry type on disclosure in the annual reports of Japanese listed corporations. The study suggested that there is a significant and positive relationship between company size and performance. In addition, Athanasoglou et al. (2008) asserted that increase in company size increases the performance of the bank. Furthermore, Almajali et al. (2012) argued that the size of the firm can positively affect its financial performance. Based on it, this study develops the following hypothesis:

$\mathrm{H1}$ : There is a positive relationship between firm size and firm profitability.

Liquidity

Pradhan and Shrestha (2015) found that liquidity is negatively and insignificantly related to return on equity. Similarly, Pradhan (2014) found that liquidity is negatively related to firm profitability. Likewise, Eljelly (2004) examined the association between profitability and liquidity of joint stock companies in Saudi Arabia using correlation and regression analysis. The study revealed that there is a negative relationship between liquidity and profitability of Saudi companies. Similarly, Molyneux and Thornton (1992) and Goddard et al. 
(2004) found a negative relationship between liquidity and profitability for European banks in the late 1980s and mid-1990s, respectively. The study argued that, holding liquid assets imposes an opportunity cost on the bank given their low return relative to other assets, thereby having a negative effect on profitability. According to Panigrahi (2014), increasing profitability would tend to reduce firm's liquidity and too much attention on liquidity would tend to affect the profitability. Lyroudi and McCarty (1993), using the listed companies of London Stock Exchange for 4 years period, revealed that the cash conversion cycle, current ratio and the quick ratio have a negative association with the profitability ratios like net profit ratio, return on assets and the return on equity. Based on it, this study develops the following hypothesis:

$\mathrm{H} 2$ : There is a negative relationship between liquidity and firm profitability.

Tangibility assets

Pradhan et al. (2020) found that tangibility assets have a positive impact on the Nepalese Insurance companies. Likewise, Mehari and Aemiro (2013) examined the firm specific factors that determine insurance companies' performance in Ethiopia. The study revealed that there is a positive relationship between tangibility and profitability of insurance companies. Similarly, Cekrezi (2013) found that tangibility has a significant positive effect on firm profitability. Moreover, Bhutta and Hasan (2013) examined the impact of firm specific and macroeconomic factors on profitability of food sector in Pakistan. The study revealed that tangibility, growth of the firm and inflation are positively related to profitability. Kodongo et al. (2015) investigated the relationship between leverage and the financial performance of listed firms in Kenya. The results showed that asset tangibility, sales growth and firm size are important determinants of profitability. The study also concluded that asset tangibility has a positive relationship with the firm profitability. Based on it, this study develops the following hypothesis:

$H_{3}$ : There is a positive relationship between assets tangibility and firm profitability.

Firm age

Pradhan et al. (2020) found that firm age has a positive impact on the profitability of Nepalese Insurance companies. Likewise, Lumpkin and Dess(1999) found that there is a positive relationship between companies' age and profitability. Pervan et al. (2012) assessed the factors affecting the profitability of the insurance companies between 2005 and 2010. The study found that there is positive relationship between firm age and profitability. Moreover, Malik (2011) found that there is significantly positive relationship between company size and profitability in the context of Pakistani firms. Moreover, Sorensen and Stuart (2000) argued that companies age affect the firm's performance. Further, the study argued that organizational inertia operating in old firms tends to make them more efficient and profitable. In addition, Liargovas and Skandalis (2008) reported that older firms are more skilled since they have enjoyed the benefits of learning and not prone to the liabilities of newness, hence they have a superior performance. Based on it, this study develops the following hypothesis:

H4: There is a positive relationship between firm age and firm profitability. 


\section{Premium growth}

Premium revenue is the primary source of revenue for most insurers. Using a dynamic panel model with GMM estimator, Dahal et al. (2020) examined the liquidity management and financial performance of Nepalese insurance companies. The results showed that insurance premium has positive impact on return on assets and earning per share. Moreover, Pervan et al. (2012) showed that there is positive relationship between premium growth rate and firm profitability. Furthermore, Akotey et al. (2013) analyzed the financial performance of life insurance companies in Ghana. The study indicated that gross premiums have a positive relationship with the profitability of insurance. Similarly, Kripa and Ajasllari (2016) assessed the factors affecting the profitability of insurance companies in Albania. The study found that the growth rate is positively associated with profitability. Based on it, this study develops the following hypothesis:

H5: There is a positive relationship between premium growth and firm profitability.

\section{Results and discussion}

Table 2 presents the descriptive statistics of the selected dependent and independent variables during the period 2011/12 to 2018/19. This table shows the descriptive statistics of dependent and independent variables of 21 Nepalese insurance companies for the study period from 2011/12 to 2018/19. The dependent variables are ROA (Return on assets is measured as the ratio of net income to total assets, in percentage) and ROE (Return on equity is measured as the ratio of net income to shareholder equity, in percentage). The independent variables are LIQ (Liquidity is measured as the ratio of current assets to current liabilities), TA (Tangibility assets is measured as the total fixed assets to total assets, in percentage), PG (Premium growth is measured by the percentage growth of gross written premiums), FS (Firm size is measured as total assets of insurance companies, Rs in billion) and AF (Age of the company is measured as the number of years from the date of establishment, in years).

Table 2: Descriptive statistics of variables

\begin{tabular}{lrrrr}
\hline Variables & \multicolumn{1}{c}{ Minimum } & Maximum & Mean & \multicolumn{1}{c}{ Std. Deviation } \\
\hline ROA & -113.00 & 54.17 & 11.02 & 14.80 \\
ROE & -505.11 & 100.70 & 12.45 & 46.39 \\
TA & 0.40 & 84.00 & 12.41 & 17.91 \\
LIQ & 0.05 & 31.00 & 3.40 & 4.08 \\
PG & -44.0 & 98.54 & 24.07 & 22.11 \\
AF & 5.0 & 71.00 & 18.87 & 12.58 \\
FS & 0.12 & 73.74 & 5.24 & 11.26 \\
\hline
\end{tabular}

Source: SPSS output

Table shows the bivariate Pearson's correlation coefficients of dependent and independent variables of 21 Nepalese insurance companies for the study period from 2011/12 to 2018/19. The dependent variables are ROA (Return on assets is measured as the ratio of net income to total assets, in percentage) and ROE (Return on equity is measured as the ratio of net income to shareholder equity, in percentage). The independent variables are LIQ (Liquidity is measured as the ratio of current assets to current liabilities), TA (Tangibility assets is 
measured as the total fixed assets to total assets, in percentage), PG (Premium growth is measured by the percentage growth of gross written premiums), FS (Firm size is measured as total assets of insurance companies, Rs in billion) and AF (Age of the company is measured as the number of years from the date of establishment, in years). Having indicated the descriptive statistics, Pearson's correlation coefficients are computed and the results are presented in Table 3.

Table 3: Pearson's correlation coefficients matrix

\begin{tabular}{|c|c|c|c|c|c|c|c|}
\hline Variables & ROA & ROE & TA & LIQ & PG & $\mathrm{AF}$ & FS \\
\hline ROA & 1 & & & & & & \\
\hline ROE & $0.649 * *$ & 1 & & & & & \\
\hline TA & 0.179* & $0.201^{* *}$ & 1 & & & & \\
\hline LIQ & -0.116 & $-0.264^{* *}$ & $-0.223^{* *}$ & 1 & & & \\
\hline PG & 0.067 & 0.047 & 0.088 & 0.620 & 1 & & \\
\hline $\mathrm{AF}$ & $0.151^{*}$ & 0.098 & -0.081 & 0.079 & -0.007 & 1 & \\
\hline FS & $0.180 *$ & $0.172 *$ & $0.158 *$ & $-0.326 * *$ & -0.057 & $-0.303^{* *}$ & 1 \\
\hline
\end{tabular}

Note: The asterisk signs $\left({ }^{* *}\right)$ and $\left({ }^{*}\right)$ indicate that the results are significant at one percent and five percent levels respectively.

Table 3 shows that firm size is positively correlated to return on assets. It indicates that larger firm size leads to increase in return on assets. Likewise, premium growth is positively correlated to return on assets. It indicates that higher the premium growth, higher would be the return on assets. Moreover, firm age is positively to return on assets. It indicates that increase in firm age leads to increase in return on assets. Moreover, assets tangibility is positively correlated to return of assets. It means that higher the assets tangibility, higher would be the return of assets. Likewise, there is a negative relationship between liquidity ratio and return on assets. It means that increase in liquidity ratio leads to decrease in return on assets.

On the other hand, firm size is positively correlated to return on equity. It indicates that larger the firm size, higher would be the return on equity. It indicates that increase in firm age leads to increase in return on equity. Similarly, premium growth has a positive relationship with return on equity. It reveals that increase in premium growth leads to increase in return on equity. Moreover, assets tangibility is positively correlated to return on equity. It means that higher the assets tangibility, higher would be the return on equity. Likewise, there is a negative relationship between liquidity ratio and return on equity. It means that increase in liquidity ratio leads to decrease in return on equity.

Regression analysis

Having indicated the Pearson's correlation coefficients, the regression analysis has been carried out and results are presented in Table 4. The results are based on panel data of 21 insurance companies with 168 observations for the period from 2011/12-2018/19 by using the linear regression model and the model is ROA it $=\beta_{0}+\beta_{1} T A_{i t}+\beta_{2} L I Q_{i t}+\beta_{3} P G_{i t}+\beta_{4} A F_{i t}+\beta_{5} F S_{i t}+e_{i t}$ where, the dependent variable is ROA (Return on assets is measured as the ratio of net income to total assets, in percentage). The independent variables are LIQ (Liquidity is measured as the ratio of current assets to current liabilities), TA (Tangibility assets is measured as the total fixed assets to total assets, in percentage), PG (Premium growth is measured by the percentage growth of gross written premiums), FS (Firm size is measured as total assets of insurance companies, Rs in billion) and AF (Age of the company is measured as the number of years from the date of establishment, in years). More specifically, it 
shows the regression results of tangibility, liquidity, premium growth, firm age and firm size on return on assets of Nepalese insurance companies.

Table 4: Estimated regression of tangibility, liquidity, premium growth, firm age and firm size with return on assets

\begin{tabular}{|c|c|c|c|c|c|c|c|c|c|}
\hline \multirow[t]{2}{*}{ Model } & \multirow[t]{2}{*}{ Intercept } & \multicolumn{5}{|c|}{ Regression coefficients of } & \multirow{2}{*}{$\begin{array}{c}\text { Adj. } \\
\text { R_bar }\end{array}$} & \multirow[t]{2}{*}{ SEE } & \multirow[t]{2}{*}{ F-value } \\
\hline & & TA & LIQ & PG & $\mathrm{AF}$ & FS & & & \\
\hline 1 & $\begin{array}{r}11.078 \\
(6.188) * *\end{array}$ & & & & & & 0.061 & 14.852 & 5.008 \\
\hline 2 & $\begin{array}{r}9.577 \\
(6.934) * *\end{array}$ & $\begin{array}{r}0.117 \\
(1.837)\end{array}$ & & & & & 0.014 & 14.704 & 3.374 \\
\hline 3 & $\begin{array}{r}14.481 \\
(10.105)^{* *}\end{array}$ & & $\begin{array}{r}-1.015 \\
(3.761) \\
* *\end{array}$ & & & & 0.073 & 14.262 & 14.152 \\
\hline 4 & $\begin{array}{r}10.941 \\
(8.017)^{* *}\end{array}$ & & & $\begin{array}{r}0.003 \\
(0.114 \\
)\end{array}$ & & & 0.006 & 14.851 & 0.013 \\
\hline 5 & $\begin{array}{r}10.905 \\
(5.268)^{* *}\end{array}$ & & & & $\begin{array}{r}0.006 \\
(0.071\end{array}$ & & 0.006 & 14.852 & 0.005 \\
\hline 6 & $\begin{array}{r}12.558 \\
(10.187)^{* *}\end{array}$ & & & & ) & $\begin{array}{r}0.322 \\
(3.234) \\
* *\end{array}$ & 0.054 & 14.485 & 8.642 \\
\hline 7 & $\begin{array}{r}10.397 \\
(5.749)^{* *}\end{array}$ & $\begin{array}{r}0.833 \\
(1.964)^{*}\end{array}$ & & & & & 0.011 & 14.722 & 1.929 \\
\hline 8 & $\begin{array}{r}16.671 \\
(6.961)^{* *}\end{array}$ & $\begin{array}{r}0.985 \\
(1.967)^{*}\end{array}$ & $\begin{array}{r}-1.097 \\
(3.762) \\
* *\end{array}$ & & & & 0.084 & 14.171 & 9.113 \\
\hline 9 & $\begin{array}{r}16.104 \\
(6.421)^{* *}\end{array}$ & $\begin{array}{r}0.909 \\
(1.962)^{*}\end{array}$ & $\begin{array}{r}-1.096 \\
(3.751) \\
* *\end{array}$ & $\begin{array}{r}0.05 \\
(0.178 \\
\text { ) }\end{array}$ & & & 0.079 & 14.213 & 14.572 \\
\hline 10 & $\begin{array}{r}16.526 \\
(5.400)^{* *}\end{array}$ & $\begin{array}{r}0.989 \\
(1.985)^{*}\end{array}$ & $\begin{array}{r}-1.107 \\
(3.734) \\
* *\end{array}$ & $\begin{array}{r}0.006 \\
(0.163 \\
)\end{array}$ & $\begin{array}{r}0.022 \\
(0.242 \\
\text { ) }\end{array}$ & & 0.073 & 14.252 & 13.644 \\
\hline 11 & $\begin{array}{r}17.723 \\
(5.702)^{* *}\end{array}$ & $\begin{array}{r}0.997 \\
(1.986)^{*}\end{array}$ & $\begin{array}{r}-0.884 \\
(2.850) \\
* *\end{array}$ & $\begin{array}{r}0.040 \\
(0.164 \\
)\end{array}$ & $\begin{array}{r}0.012 \\
(0.138 \\
)\end{array}$ & $\begin{array}{r}0.273 \\
(2.536)^{*}\end{array}$ & 0.103 & 14.092 & 14.209 \\
\hline
\end{tabular}

Notes: Figures in parenthesis are t-values. The asterisk signs $\left({ }^{* *}\right)$ and $\left({ }^{*}\right)$ indicate that the results are significant at one percent and five percent levels respectively. Return on asset is the dependent variable.

Table 4 shows that the beta coefficients for firm size are positive with return on assets. It indicates that firm size has a positive impact on return on assets. This finding is similar to the findings of Dey et al. (2015). Similarly, the beta coefficients for firm age are positive with return on assets. It indicates that firm age has a positive impact on return on assets. This finding is consistent with the findings of Pervan et al. (2012). Similarly, the beta coefficients for assets tangibility are positive with return on assets. It indicates that assets tangibility has a positive impact on return on assets. This finding is consistent with the findings of Kodongo et al. (2015). Likewise, the beta coefficients for liquidity ratio are negative with return on assets. It indicates that liquidity ratio has a negative impact on return on assets. This finding is similar to the findings of Panigrahi (2014).

Table 5 shows the regression results of leverage, tangibility, liquidity, premium growth, firm age and firm size on return on assets of Nepalese insurance companies. The results are based on panel data of 21 
insurance companies with 168 observations for the period from 2011/12-2018/19 by using the linear regression model and the model is ROEit $=\beta 0+\beta 1$ TA it $+\beta 2 \mathrm{LIQ}$ it $+\beta 3$ PG it $+\beta 4 \mathrm{AF}$ it $+\beta 5 \mathrm{FS}$ it + eit where, the dependent variable is ROE (Return on equity is measured as the ratio of net income to shareholder equity, in percentage). The independent variables are LIQ (Liquidity is measured as the ratio of current assets to current liabilities), TA (Tangibility assets is measured as the total fixed assets to total assets, in percentage), PG (Premium growth is measured by the percentage growth of gross written premiums), FS (Firm size is measured as total assets of insurance companies, Rs in billion) and AF (Age of the company is measured as the number of years from the date of establishment, in years).

Table 5: Estimated regression of tangibility, liquidity, premium growth, firm age and firm size with return on equity

\begin{tabular}{|c|c|c|c|c|c|c|c|c|c|}
\hline \multirow[t]{2}{*}{ Model } & \multirow[t]{2}{*}{ Intercept } & \multicolumn{5}{|c|}{ Regression coefficients of } & \multirow[t]{2}{*}{ Adj. R_bar ${ }^{2}$} & \multirow[t]{2}{*}{ SEE } & \multirow[t]{2}{*}{ F-value } \\
\hline & & TA & LIQ & PG & $\mathrm{AF}$ & FS & & & \\
\hline 1 & $\begin{array}{r}15.901 \\
(2.856)^{* *}\end{array}$ & & & & & & 0.114 & 46.181 & 10.861 \\
\hline 2 & $\begin{array}{r}9.076 \\
(2.097)^{*}\end{array}$ & $\begin{array}{r}0.230 \\
(1.956)\end{array}$ & & & & & 0.025 & 46.114 & 1.340 \\
\hline 3 & $\begin{array}{r}16.220 \\
(3.507)^{* *}\end{array}$ & & $\begin{array}{r}-1.259 \\
(1.985)^{*}\end{array}$ & & & & 0.076 & 46.011 & 8.094 \\
\hline 4 & $\begin{array}{r}12.424 \\
(2.920)^{* *}\end{array}$ & & & $\begin{array}{r}0.018 \\
(0.210)\end{array}$ & & & 0.016 & 46.297 & 1.045 \\
\hline 5 & $\begin{array}{r}10.432 \\
(1.617)^{*}\end{array}$ & & & & $\begin{array}{r}0.080 \\
(0.280)\end{array}$ & & 0.012 & 46.291 & 1.084 \\
\hline 6 & $\begin{array}{r}19.199 \\
(12.455)^{* *}\end{array}$ & & & & & $\begin{array}{r}0.394 \\
(1.965)^{*}\end{array}$ & 0.053 & 45.084 & 6.545 \\
\hline 7 & $\begin{array}{r}14.202 \\
(2.515)^{*}\end{array}$ & $\begin{array}{r}0.331 \\
(1.570)\end{array}$ & & & & & 0.088 & 45.986 & 11.667 \\
\hline 8 & $\begin{array}{r}22.553 \\
(2.991)^{* *}\end{array}$ & $\begin{array}{r}0.269 \\
(1.262)\end{array}$ & $\begin{array}{r}-.1562 \\
(1.960)^{*}\end{array}$ & & & & 0.118 & 45.744 & 12.044 \\
\hline 9 & $\begin{array}{r}22.254 \\
(2.873)^{* *}\end{array}$ & $\begin{array}{r}0.266 \\
(1.241)\end{array}$ & $\begin{array}{r}-1.566 \\
(1.969)^{*}\end{array}$ & $\begin{array}{r}0.021 \\
(0.243)\end{array}$ & & & 0.113 & 45.877 & 11.547 \\
\hline 10 & $\begin{array}{r}20.933 \\
(2.120) *\end{array}$ & $\begin{array}{r}0.278 \\
(1.281)\end{array}$ & $\begin{array}{r}-1.508 \\
(1.977)^{*}\end{array}$ & $\begin{array}{r}0.081 \\
(0.218)\end{array}$ & $\begin{array}{r}0.122 \\
(0.413)\end{array}$ & & 0.128 & 45.986 & 15.277 \\
\hline 11 & $\begin{array}{r}23.277 \\
(2.326)^{*}\end{array}$ & $\begin{array}{r}0.300 \\
(1.382)\end{array}$ & $\begin{array}{r}-1.018 \\
(1.961)^{*}\end{array}$ & $\begin{array}{r}0.018 \\
(0.219)\end{array}$ & $\begin{array}{r}0.141 \\
(0.477)\end{array}$ & $\begin{array}{r}0.478 \\
(1.972)^{*}\end{array}$ & 0.112 & 45.874 & 11.340 \\
\hline
\end{tabular}

Notes: Figures in parenthesis are $t$-values. The asterisk signs $\left({ }^{* *}\right)$ and $\left({ }^{*}\right)$ indicate that the results are significant at one percent and five percent levels respectively. Return on equity is the dependent variable.

Table 5 shows that the beta coefficients for premium growth are positive with return on equity. It indicates that premium growth has a positive impact on return on equity. This finding is similar to the findings of Kripa and Ajasllari (2016). Similarly, the beta coefficients for firm size are positive with return on equity. It indicates that firm size has a positive impact on return on equity. This finding is consistent with the findings of Athanasoglou et al. (2008). Similarly, the beta coefficients for assets tangibility are positive with return on equity. It indicates that assets tangibility has a positive impact on return on equity. This finding is consistent with the findings of Cekrezi (2013). Likewise, the beta coefficients for liquidity ratio are negative with return on equity. It indicates that liquidity ratio has a negative impact on return on equity. This finding is similar to the findings of Lyroudi and McCarty (1993). 


\section{Conclusion}

Good performance of a company determines the position of the company in its market and the growth and consolidation of the market. Profitability is one of the most important objectives of financial management, since one of the main tasks and goals of financial management is to increase shareholders wealth. The variation of profits between insurance companies over the years, within a country, leads to believe that internal factors or specific factors of a firm play a major role in determining profitability. This study attempts to analyze the factors affecting the profitability of Nepalese insurance companies. This study is based on secondary data of 21 insurance companies with 168observations for the study period from 2011/12 to 2018/19.

The study showed that tangibility, premium growth, firm age and firm size have positive impact on return on assets of Nepalese insurance companies. The study also showed that tangibility, premium growth, firm age and firm size have positive impact on return on equity. However, liquidity ratio has a negative impact on return on equity and return on assets of Nepalese insurance companies. The study concluded that leverage followed by liquidity is the most influencing factor that explains the changes in the return on equity. Likewise, the study also concluded that liquidity followed by firm size is the most influencing factor that explains the changes in the return on assets in the context of Nepalese insurance companies.

\section{Acknowledgements}

The authors would like to thank Branch Managers of various Insurance Companies situated in Kathmandu Valley for providing me other information about their respective branch.

\section{Declaration of conflicting interests}

The authors declare no conflict of interest.

\section{Funding}

This research received no grant from any funding agency.

\section{Author contributions}

Conceptualization: Sah; Magar. Methodology: Sah; Magar. Software: Sah. Validation: Sah. Formal Analysis: Sah. Investigation: Magar. Data Curation: Sah. Writing - Original Draft: Sah. Writing - Review \& Editing: Sah; Magar. Visualization: Magar. Supervision: Magar.

\section{Ethical statement}

This research did not require ethical approval as it does not involve any human or animal experiment.

\section{Data availability statement}

Data have been used only for this paper.

\section{ORCID information}

Laxmi Kumar Sah, ORCID: 0000-0002-1610-3819

\section{References}

Ahmed, N., Ahmed, Z., \& Usman, A. (2011). Determinants of performance: A case of life insurance sector of Pakistan. International Research Journal of Finance and Economics, 61(1), 123-128.

Akotey, J., Sackey, F., Amoah, L., \& Manso, R. (2013). The financial performance of life insurance companies in Ghana. The Journal of Risk Finance, 14(3), 286-302.

Almajali, A. Y., Alamro, S. A., \& Al-Soub, Y. Z. (2012). Factors affecting the financial performance of Jordanian insurance companies listed at Amman Stock Exchange. Journal of Management Research, 4(2), 266-278.

Antoniou, A., Guney, Y., \& Paudyal, K. (2008). The determinants of capital structure: Capital-market oriented versus bank-oriented institutions. Journal of Financial and Quantitative Analysis, 43(2), 59- 92.

Aregawi, H. T., Patnaik, C. M., \& Satpathy, I. (2018). Detreminants of leverage and its impact firm performance in Ethiopian insurance industary. International Journal of Mechanica Engineering and Technology (IJMET), 9(13), 890-905. 
Athanasoglou, P. P., Brissimis, S. N., \& Delis, M. D. (2008). Bank-specific, industry-specific and macroeconomic determinants of bank profitability. Journal of International Financial Markets, Institutions and Money, 18(2), 121-136.

Bevan, N., Alan, A., \& Danbolt, J. (2002). Capital structure and its determinants in the United Kingdom: A decomposition analysis. Applied Financial Economics, 12(3), 159-170.

Bhutta, N. T., \& Hasan, A. (2013). Impact of firm specific factors on profitability of firms in food sector. Scientific Research, 2(2), 113-1119.

Browne, M. J., Carson, J. M., \& Hoyt, R. E. (2001). Dynamic financial models of life insurers. North American Actuarial Journal, 5(2), 11-26.

Budhathoki, A., Syangtan, A., Shah, A. K., Aryal, A., \& Prajapati, A. (2020). Impact of non-performing loans on bank's profitability of Nepalese commercial banks. Nepalese Journal of Business, 7(3), 116-127.

Burca, A. M., \& Batrinca, G. (2014). The determinants of financial performance in the Romanian insurance market. International Journal of Academic Research in Accounting, Finance and Management Sciences, 4(1), 299-308.

Cekrezi, A. (2013). Impact of firm level factors on capital. European Journal of Sustainable Development, 2(4), 135148.

Chen, J., Chen, M., Liao, W., \& Chen, T. (2009). Influence of capital structure and operational risk on profitability of life insurance industry in Taiwan. Journal of Modelling in Management, 4(1), 7-18.

Cooke T. E. (1992). The impact of size, stock market listing and industry type on disclosure in the annual reports of Japanese listed corporations. Accounting and Business Research, 22(8), 229-237.

Curak, M., Pepur, S., \& Poposki, K. (2011). Firm and economic factors and performance: Croatian composite insurers. The Business Review Cambridge, 19(1), 136-142.

Dahal, P., Timalsena, P., Sah, P., \& Sah, P. (2020). Liquidity management and financial performance of Nepalese insurance companies. Nepalese Journal of Business, 7(3), 137-146.

Dey, N. B., Adhikari, K., \& Bardhan M. R. (2015). Factors determining financial performance of life insurance companies of India - An empirical study. International Journal of Economic and Business Review, 3(8), 4248.

Ejigu, S. N. (2016). Determining internal factors affecting financial performance of insurance companies in Ethiopia. Research Journal of Commerce and Behavioral Science, 5(6), 9-21.

Eljelly, A. M. (2004). Liquidity-profitability tradeoff: An empirical investigation in an emerging market. International Journal of Commerce and Management, 14(2), 48-61.

Goddard, J., Molyneux, P., \& Wilson, J. O. (2004). Dynamics of growth and profitability in banking. Journal of Money, Credit and Banking, 36(2), 1069-1090.

Greene, W. H., \& Segal, D. (2004). Profitability and efficiency in the US life insurance industry. Journal of Productivity Analysis, 21(3), 229-247.

Ikonic, D., Arsic, N., \& Milosevic, S. (2011). Growth potential and profitability analysis of insurance companies in the Republic of Serbia. Chinese Business Review, 10(11), 998-1008.

Ismail, R. (2016). Impact of liquidity management on profitability of Pakistani firms. International Journal of Innovation and Applied Studies, 14(2), 304-314.

Jaishi, B., \& Poudel, R. L. (2021). Impact of firm specific factors on financial performance: A comparative study of life and non-life insurance companies in Nepal. Prithvi Academic Journal, 4(2), 39-55.

Kodongo, O., Mokoaleli-Mokoteli, T., \& Maina, L. N. (2015). Capital structure, profitability and firm value: Panel evidence of listed firms in Kenya. African Finance Journal, 17(1), 1-20.

Kozak, S. (2011). Determinants of profitability of non-life insurance companies in Poland during integration with the European financial system. Electronic Journal of Polish Agricultural Universities, 14(1), 1-9. 
Kripa, D., \& Ajasllari, D. (2016). Factors affecting the profitability of insurance companies in Albania. European Journal of Multidisciplinary Studies, 1(1), 352-360.

Liargovas, P., \& Skandalis, K. (2008). Factor affecting firm's financial performance: The case of Greece. Athens: University of Peloponnese Press.

Lumpkin, G., \& Dess, G. (1999). Linking two dimensions of entrepreneurial orientation to firm performance: The moderating role of environment, firm age, and industry life cycle. Journal of Business Venturing, 16(5), 429-451.

Lyroudi, K., \& McCarty, D. (1993). An empirical investigation of the cash conversion cycle of small business firms. Journal of Small Business Finance, 2(2), 139-161.

Malik, H. (2011). Determinants of insurance companies' profitability: An analysis of insurance sector of Pakistan. Academic Research International, 1(3), 315-321.

Mehari, D., \& Aemiro, T. (2013). Firm specific factors that determine insurance companies' performance in Ethiopia. European Scientific Journal, 9(10), 857-881.

Molyneux, P., \& Thornton, J. (1992). Determinants of European bank profitability: A note. Journal of Banking and Finance, 16(6), 1173-1178.

Mwangi, M., \& Murigu, J. W. (2015). The determinants of financial performance in general insurance companies in Kenya. European Scientific Journal January, 1(11), 288-297.

Ojha, P. R. (2018). Macroeconomics and bank-specific factors affecting liquidity: A study of Nepali commercial banks. Journal of Business and Social Sciences, 2(1), 79-87.

Onaolapo, A., \& Kajola, S. (2010). Capital structure and firm performance: Evidence from Nigeria. European Journal of Economics, Finance and Administrative Sciences, 25(6), 70-82.

Panigrahi, C. M. A. (2014). Relationship of working capital with liquidity, profitability and solvency: A case study of ACC Limited. Asian Journal of Management Research, 4(2), 308-322.

Pervan, M., Curak, M., \& Mariajnovic, I. (2012). Dynamic panel analysis of BandH insurance companies' profitability. Recent Researches in Business and Economics, 1(1), 158-163.

Poudel, B. (2019). Impact of ownership structure on the profitability of Nepalese insurance companies. Nepalese Journal of Business, 6(3), 52-65.

Pradhan, R. S. (2014). Bank specific and macroeconomic determinants of bank profitability: A case of Nepal. Nepalese Journal of Finance, 1(1), 1-11.

Pradhan, R. S., \& Shrestha, P. (2015). Impact of bank specific and macroeconomic variables on the performance of commercial banks of Nepal. Nepalese Journal of Business, 2(1), 73-84.

Shiu, Y. (2004). Determinants of United Kingdom general insurance company performance. British Actuarial Journal, 10(5), 1079-1110.

Sorensen, B., \& Stuart, E. (2000). Age, obsolescence, and organizational innovation. Academy of Management Journal, 25(6), 121 - 132.

Upadhyaya, S. (2020). Relationship between cash flow and financial performance of Nepalese commercial banks. Nepalese Journal of Economics, 4(2), 124-139. 